\title{
LAS DIEZ NOVELAS DE PEDRO DE SALAZAR Y LOS CUATRO CUENTOS DE EJEMPLOS. AUTORÍA COMÚN Y ESTRUCTURA COMPARTIDA ${ }^{1}$
}

En 1983, José Manuel Blecua ofreció como homenaje a Lázaro Carreter unas notas muy sucintas sobre una obra manuscrita y desconocida hasta entonces que iluminaba sorprendentemente los orígenes de la novella, es decir, de la novela corta en España ${ }^{2}$. Se trataba de las Diez novelas o cuentos -que de las dos formas denomina el autor sus narraciones ${ }^{3}-$, de Pedro de Salazar ${ }^{4}$, cronista de Carlos V y Felipe II, y padre del poeta y jurista Eugenio de Salazar. Blecua tuvo acceso al manuscrito gracias a su poseedor, D. Bartolomé March $^{5}$, que lo había

1 Una primera versión de este trabajo se leyó en el VIII Congreso de la AISO, celebrado en Santiago de Compostela, del 7 al 11 de julio de 2008.

2 José Manuel Blecua Perdices, "Notas para la historia de la novela en España”, en Serta Philologica F. Lázaro Carreter, Cátedra, Madrid, 1983, t. 2, pp. 91-95.

3 Salazar parece distinguir entre cuento, como término patrimonial, y novela, en tanto que su correspondiente italiano: "Mas considerando que en la sazón presente V. M. tiene más nescesidad de lecturas que le recreen, que de leer las variedades y peligros de la guerra, a causa de haber sacado tan poco tiempo ha sus reales manos de la masa de tantas armas como estos pasados años ha tocado, determiné de servirle con la obra presente, que es de cuentos, que los italianos llaman novellas, y antiguamente en Castilla llamaron consejas, por los buenos consejos y ejemplos que de ellos colegirse pueden" (f. 3). También iguala constantemente novela y cuento, utilizándolos como sinónimos intercambiables, Lucas Gracián Dantisco, Galateo español, XVII, ed. M. Morreale, CSIC, Madrid, 1968, p. 155.

${ }^{4}$ Para la biografía de Salazar, véase el art. cit. de Blecua y la entrada de José Solís de los Santos al Diccionario biográfico español de la Real Academia de la Historia, quien amablemente la ha puesto a mi disposición.

${ }^{5}$ Ahora se encuentra en la Fundación de Palma de Mallorca con signatura B89-VI-05. En la sede de Madrid se catalogaba con signatura 21/7/3, Registro 6953. 
adquirido en una subasta en Londres, procedente de la importante biblioteca de sir Thomas Phillips ${ }^{6}$. March amablemente se lo prestó para que lo estudiara y, según comenta Blecua, con el fin de realizar una edición para Clásicos Castellanos. Esta edición nunca llegó a ver la luz y, salvo uno de los cuentos ${ }^{7}$, o al menos es lo que conozco, el resto permanece inédito, aunque la colección ha sido citada, siempre por medio de Blecua, por Jesús Gómez, José Manuel Pedrosa e Isabel Colón Calderón ${ }^{8}$, entre otros.

\section{HACIA UNA DATACIÓN}

Ahora bien, por más que las novelas hayan quedado manuscritas, la pretensión de Salazar -como la muy conocida de su hijo Eugenio, que dispuso todos los detalles para que se llevara a cabo la impresión de su Silva de poesía ${ }^{9}$-, parece ser la de ofrecer un texto, no sabemos si autógrafo o no, cabalmente dispuesto para la imprenta. El caso es que, aunque el códice carece de portada, que tal vez se haya perdido ${ }^{10}$, contiene una Dedicato-

${ }^{6}$ Se trata de un manuscrito de 271 folios más dos hojas sin numerar de $210 \times 150 \mathrm{~mm}$, encuadernado en piel marrón (restaurada quizá por March) con cantos y relieves dorados, preservado en un estuche de tela y piel granate. En el lomo se lee: Pedro de Salazar, novelas.

7 Exactamente el noveno, véase, en adelante, publicado en Prodigios y pasiones. Doce cuentos españoles del siglo XVI, ed. G. Pontón, Muchnik, Barcelona, 1999, pp. 101-12.

8 Jesús Gómez, "Boccaccio y Otálora en los orígenes de la novela corta en España”, en Estudios sobre el diálogo renacentista español. Antología de la crítica, eds. A. Rallo Gruss y R. Malpartida Tirado, Universidad, Málaga, 2006, pp. 269-289; José Manuel Pedrosa, El cuento popular en los Siglos de Oro, Laberinto, Madrid, 2004, pp. 83 y 269, e Isabel Colón Calderón, La novela corta en el siglo XVII, Laberinto, Madrid, 2001, p. 16.

9 El ms. C-56 de la Real Academia de la Historia, donde se copia el poemario, lo describió Bartolomé José Gallardo, Ensayo de una biblioteca española de libros raros y curiosos, Rivadeneyra y Tello, Madrid, 1863-1889, t. 4, cols. 326-395 y ha sido editado en parte por Jaime J. Martínez Martín (Bulzoni, Roma, 2004). Todas las recomendaciones de Salazar aparecen en dos hojas al principio del manuscrito, donde da instrucciones a sus hijos para que se hagan cargo de la edición. El esbozo más completo sobre el poeta lo hace Antonio Prieto, La poesía española del siglo XVI, Cátedra, Madrid, 1987, t. 2, pp. 655-667. 2238.

${ }^{10}$ Lo primero que aparece es el exlibris de Phillips con la signatura 
ria a Felipe $\mathrm{II}^{11}$, que sirve como Prólogo $\mathrm{o}^{12}$, y luego, al final, una Tabla de los cuentos que hay en esta primera parte ${ }^{13}$ y una Tabla de los primeros versos de los poemas incluidos en algunos de ellos $^{14}$. Además, se ponen signaturas (siguiendo el orden alfabético, A, B, C...) a cada cuaderno y también epígrafes (Cuento $1^{\circ}, 2^{\circ}$, etc.) en el recto de los folios.

Asimismo, hay otra particularidad digna de tomarse en consideración. Argumenta Salazar en la Dedicatoria:

Y porque algunos de los cuentos que escribo son largos, e no siempre cualquiera de ellos se podrá pasar y leer de una vez, determiné numerarlos para que por sus números se puedan ir leyendo y pasando, y el que hubiere de dejar cuento comenzado para proseguir después la lectura de él, lo deje al fin del número, e cuando a él vuelva, halle con más facilidad el lugar hasta donde había leído (f. 3v).

Una práctica de segmentación en unidades narrativas más pequeñas ${ }^{15}$ que se observa en algunas colecciones españolas, como, por ejemplo, en la traducción de Bandello de 1589, y que en última instancia demuestra, como no podía ser de otro modo en el género novelesco, que las piezas están destinadas a la lectura, incluso a la lectura en voz baja.

Al margen de los aspectos codicológicos, el elemento imprescindible para situar esta obra en la trayectoria del género parte de la datación del conjunto. Tales datos pueden colegirse a partir de la cronología que ofrecen las crónicas escritas por Salazar y, sobre todo, de las menciones cruzadas que se hacen en los textos. Así, en 1548 se publica la Historia y primera parte de la

11 "A LA SACRA, CA-/ -tólica y real majestad del / cristianísimo e invictísimo don / Filipo, segundo Rey d'España, de / las dos Sicilias, de Jerusalén y de / las Indias, etc. Prólogo y dedicación de la presen- / -te Obra por Pedro de Salazar, / vecino de Madrid" (ff. 2-4; a partir de ahora se señalan los folios correspondientes sin más comentario).

12 Este importante texto lo reprodujo Blecua como apéndice de su nota (pp. 93-95).

13 A partir de este momento no aparece foliación, pero se correspondería con el f. 272-272v. [f. 273].

${ }^{14}$ Exactamente: Tabla de los sonetos y canciones en esa primera parte

${ }^{15}$ Esta división se marca con un guión y un punto y aparte precedido del ordinal en números romanos. 
guerra de Alemania ${ }^{16}$ y, en 1552, la Historia de la guerra y presa de A frica ${ }^{17}$. En la dedicatoria a Felipe II, de nuestro ms., se refiere a estas dos obras. De la primera dice Salazar: “...me atreví a Vuesa Majestad con la historia y primera parte de la guerra que el cristianísimo e invictísimo Emperador, vuestro padre, que de Dios goza $^{18}$, movió contra los rebeldes del imperio" (f. 2v). Y sobre la segunda, añade: "E después con la crónica de la famosa conquista de África...". Por su parte, de la obra que está prologando, afirma, finalmente: "E, agora, por tercera vez, me atrevo con la presente obra, aunque mal limada y en tosco estilo escrita, porque confío que vuestra real grandeza no hará caso de la entera voluntad con que se los ofrezco" (f. 2v).

Es decir, que adjudica a las novelas el tercer lugar en el orden sucesivo de escritura, después de las dos obras históricas mencionadas. Pero restaba por aparecer otra aportación sobre las hazañas imperiales en África, la Hispania victrix ${ }^{19}$, publicada en 1570 -por tanto, seis años antes de su muerte, acaecida en 1576-, aunque con aprobaciones en 1567. En la Dedicatoria, también dirigida a Felipe $\mathrm{II}^{20}$, Salazar hace una declaración de intenciones sobre el carácter veraz que ha de entrañar la obra histórica, y para ello establece un recuento de su bibliografía hasta ese momento:

Y así, recogido y recopilado, no teniendo ojo a otro que ha decir y narrar simplemente la verdad, prosiguiendo en lo que antes de agora, que es servir como servía a V. M., con la historia de la guerra

${ }^{16}$ Historia y primera parte de la Guerra que don Carlos, Quinto Emperador de los Romanos, Rey de España y Alemania, movió contra los Príncipes y Ciudades rebeldes del Reyno de Alemania y sucessos que tuvo, Nápoles, Pablo Suganappo, 1548. Con una edición pirata: Corónica de nuestro invictíssimo Emperador don Carlos Quinto deste hombre emperador de los romanos, rey de España y Alemania [...] A la qual va agora nuevamente añadido el fin que las dichas guerras tuvieron, Dominico de Robertis, Sevilla, 1552.

17 Hystoria de la guerra y presa de África, con la destruyción de la villa de Monazter y ysla del Gozo y pérfida de Tripol de Berbería, con otras muy nuevas cosas, mastre Matia (Matia Cancer de Brescia), Napoli, 1552. Hay ed. facs.: Universidad, Valencia, 1993.

${ }^{18}$ Por tanto, ya está muerto para entonces.

19 Hispania Victrix. Historia en la qual se cuentan muchas guerras succedidas entre Christianos y infieles assi en mar como en tierra desde el año de mil y quinientos y quarenta y seys hasta el de sessenta y cinco. Con las guerras acontecidas en la Berbería entre el Xarife y los reyes de Marruecos, Fez y Vélez, Vincente de Millis, Medina del Campo, 1570.

${ }^{20}$ Repite el título que utiliza en el manuscrito casi a la letra. 
que movió la SCCRM del Emperador Carlos Quinto, vuestro muy amado y reverenciado padre Nuestro Señor, de buena y gloriosa memoria, que de Dios goza, a los rebeldes al sacro imperio y de la toma y presa de África (de más del libro intitulado de cuentos) lo puse en historia, la cual de más de ser (como es) verdadera lleva consigo una muy grata delectación.

Los términos son francamente similares a los que venimos manejando, pero sobre todo confirman que el libro intitulado de cuentos fue ultimado antes de 1567 y que, en efecto, ocupa el tercer lugar en la producción total.

Así pues, las fechas incontrovertibles para la datación de la obra serían posteriores a 1558, año de la muerte del Emperador, y anteriores a 1567. Ahora bien, considero que la fecha se podría afinar algo más. En primer lugar, los argumentos de los cuentos, como luego veremos, mantienen un espíritu claramente postridentino, lo que nos llevaría a ubicarla, como mínimo, después de 1563, al menos en lo que respecta a algunos de los cuentos. Más interesante aún, por tratarse de una prueba intrínseca. Salazar constata, jactándose de su originalidad: "Y puesto que ningún español, que yo sepa, hasta agora haya escrito en este género de escritura, no vendo mi invención por nueva, pues es notorio que de muchos tiempos atrás otros muchos y muy graves autores aprobaron y usaron el escribir cuentos, y otros, consejas y novelas..." (f. 3). Advertencia que recuerda el famoso: "que yo soy el primero que he novelado en lengua castellana”, de Cervantes ${ }^{21}$, y que imposibilitaría la aparición de El Patrañuelo, de Timoneda, hasta ese momento, puesto que fue publicado en 1567, el mismo año de la fecha de licencia de la Hispania victrix. Por tanto, la datación más ajustada que propondría para las novelas estaría comprendida aproximadamente entre 1563 y $1566^{22}$. E incluso, si las palabras de Salazar también se refirieren -lo cual es discutible por las divergencias genéricas que median entre cuentos y facecias-, a las primeras

${ }^{21}$ Por supuesto son palabras del prólogo de las Novelas ejemplares: “que yo soy el primero que he novelado en lengua castellana; que las muchas novelas que en ella andan impresas, todas son traducidas de lenguas extranjeras, y éstas son mías propias, no imitadas ni hurtadas: mi ingenio las engendró y las parió mi pluma y van creciendo en los brazos de la estampa..." (MigueL de Cervantes, Novelas ejemplares, ed. J. García López, Crítica, Barcelona, 2001, p. 19).

${ }^{22}$ Téngase en cuenta que, por otra parte, la primera ed. de los Hecatommithi de Cinthio, que pudo leer Salazar, es de 1565. 
obras de Timoneda -el Sobremesa y alivio de caminantes y el Buen aviso y portacuentos-, entonces tendríamos que concluir que acaso se situarían entre 1563 y 1564. Finalmente, una mención de Eugenio de Salazar en un poema suyo, titulado la Navegación del alma, sirve para corroborar las fechas propuestas. En la dedicatoria correspondiente dice que su padre escribió un "agradable libro de novelas o cuentos... con que sirvió a su majestad (Felipe II) en el tiempo de su felicísima juventud" ${ }^{23}$. Si para esta etapa juvenil consideramos el límite en torno a los 35 años -la "perfeta edad" que menciona Garcilaso en su soneto $28^{24}$, la cronología cuadraría bastante bien con el año de 1563, dado que el rey nació en 1527.

Sea como fuere, Salazar especifica en la dedicatoria otro asunto de suma trascendencia para comprender cabalmente la naturaleza y dimensión de la obra. Afirma que estos diez cuentos son una primera entrega de un total de treinta novelas, repartidas en tres partes:

E puesto que, con la ayuda de Dios, mis cuentos llegarán a número de treinta, los he repartido en tres partes, para servir a V. M. con ellos en tres pedazos, porque de los ver todos juntos en un cuerpo no se harte y enfade, como suele acaescer a los que ven a la mesa, donde a comer se asientan, todos los platos y servicios juntos (f. 3v).

De esto se desprende que el título exacto de la colección habría de ser Primera parte de las novelas, o de los cuentos. Y nótese que un procedimiento bastante parecido lleva a cabo el autor con el proyecto de la Historia y primera parte de la guerra de Alemania, que, tras la aparición impresa en 1548, fue continuada en una segunda, aunque no publicada, conservada actualmente en el ms. \&-III-7 de la Biblioteca de El Escorial ${ }^{25}$. Así lo explica el propio autor en el manuscrito:

23 Apud J.M. BlecuA, art. cit.

24 "Sabed que en mi perfeta edad, y armado, / con mis ojos abiertos, me he rendido / al Niño que sabéis, ciego y desnudo".

25 Al que se alude en la Dedicatoria: "Historia dirigida al sereníssimo señor don Philiphe Príncipe de España compuesta por pedro de Salazar vezino de la villa de madrid de los sucessos de la guerra que la sacra cesaria católica magestad del ynuitissimo césar don carlos quinto emperador de los romanos, rrey de errata y alemania tuuo contra langraff duque de iassci prínçipes caballeros y ciudades francas reueldes del rreyno de Alemania”. 
Bien pudiera servir a Vuesa Majestad con la segunda parte de la guerra de Alemaña y con otros comentarios de otras guerras y batallas, que vuestro imperial padre emprendió y acabó prósperamente, por medio de sus excelentes capitanes, de las cuales, no con poco trabajo, me he informado y, lo mejor que he podido, las tengo para servicio vuestro, escritas (f. $2 \mathrm{v}$ ).

\section{MARCO NARRATIVO Y ESTRUCTURA}

A la vista de las fechas barajadas, queda palmaria la enorme importancia que adquiere esta colección de novelas en la trayectoria del género. Pero, sobre todo, hay que destacar que constituye, aparte de las colecciones medievales, la única, a lo largo del siglo XVI -hasta llegar a las Noches de invierno, de Eslava (1609)-, que ofrece un marco narrativo, puesto que la tendencia general, incluido Cervantes, es la de la compilación contigua, pero sin armazón contextual ${ }^{26}$. Este marco en el que se insertan las diez historias está conformado por el Fundamento a la presente obra (ff. $4 \mathrm{v}-7 \mathrm{v})$ y se continúa luego en unos comentarios que van engarzando los relatos entre sí, a imitación de las estructuras de Boccaccio y los novellieri italianos. El motivo que sustenta la cornice es el recurrente alivio de caminantes ${ }^{27}$. Un recurso que fue utilizado también en una obra manuscrita interesantísima para la historia de la novela breve en España, los Coloquios de Palatino y Pinciano, de Otálora, los cuales constituyen un primer intento -también anterior a Timoneda, pues se podrían fechar entre 1550 y 1561- de utilizar el marco dialogado para incrustar una serie de cuentos $^{28}$. Principalmente interesante es el cuarto relato (XVII, ff. 5-6) que se ubica en la estela de Boccaccio, como

${ }^{26}$ No tienen marco las narraciones de Timoneda, ni las novelas en verso de Tamariz. Tampoco aparece en la otra colección peninsular, Gonzalo Fernández Trancoso, Contos e Histórias de proveito e ejemplo, 1575 (ed. J. Palma Ferreira, Impresa Nacional, Lisboa, 1974). Para el estudio de la novelística previa a Cervantes sigue siendo imprescindible Marcelino Menéndez Pelayo, ahora en flamante reedición: Orígenes de la novela, Gredos, Madrid, 2008 (2 ts.).

27 Que aparece desde Chaucer (Cuentos de Canterbury, ed. P. Guardia, Cátedra, Madrid, 2006) al Viaje entretenido, por poner dos ejemplos bien conocidos. En Decamerón, VI, 1, este tipo de eje temático resulta ser el eje central (ed. M. Hernández Esteban, Cátedra, Madrid, 2007). Lo adopta como marco Sercambi en Il novelliere (ed. L. Rossi, Salerno, Roma, 1974). Asimismo, se propone una muestra de cuentos de camino en Melchor de Santa Cruz, Floresta española, IX, III. Véase J.M. PedrosA, op. cit., pp. 79-84.

${ }^{28}$ Los ha estudiado Jesús Gómez, fundamentalmente en "Boccaccio 
comenta Palatino: "Aína me parecerá que se va haciendo una buena novela, al tenor de las de Juan Boccaccio" 29 .

El rey visigodo Errigo ${ }^{30}$ contrae una enfermedad tan severa que todos los médicos lo dan por desahuciado. Él, sin embargo, se encomienda a Dios y poco a poco va restableciéndose. Para alcanzar la mejoría completa, uno de sus médicos le aconseja que se traslade de Toledo a Granada para pasar el verano. Con el fin de recrearse en el camino, el rey encarga a varios nobles y principales señores que le relaten "cuentos gustosos y apacibles" ${ }^{2}$. También instituye un premio para el mejor y nombra a cuatro jueces, entre obispos y nobles, para que dictaminen al respecto ${ }^{32}$. El primer narrador en tomar la palabra es el conde de Nemes y, como los otros nueve que habrán de intervenir a continuación ${ }^{33}$,

y Otálora...", pero, anteriormente, en "Las formas del relato breve en los Coloquios de Palatino y Pinciano", RLit, 54 (1992), 75-99.

29 Juan de Arce de Otálora, Coloquios de Palatino y Pinciano, ed. L. Ocasar Ariza, Turner, Madrid, 1995, t. 2, p. 1398.

30 "Antes que el sin ventura rey don Rodrigo fuese de su real trono derribado y privado de la corona de España por la pérdida y destruición que de ella le sobrevino, reinó en estos reinos un rey, sucesor del buen Bamba y cuarto predecesor suyo, nombrado Errigo, el cual era muy justiciero y humano, afable y dadivoso, y por esto de todos sus vasallos amado, servido y obedecido con voluntad crecida y lealtad entera" (f. 4v).

31 “....siendo ya de Toledo un cuarto de legua alejado, el rey dijo: -Yo querría que para que no sintiésemos el trabajo del camino llevásemos hasta Granada alguna manera de pasatiempo. Oyendo esto Juliano, el buen arzobispo de Toledo -murió santo-, que con el rey iba, le dijo: -Vuestra alteza escoja la que será más agradable, que todos le pornemos, desde luego, por obra, porque no llevamos mayor deseo que evitarle la pesadumbre de esta jornada. -Pues en mi elección lo dejáis -dijo el rey-, lo que más gusto me da será oír contar algunos cuentos gustosos y apacibles, porque para en camino no hay pasatiempo más aparejado y más consumidor del trabajo que éste" (ff. 5v-6).

${ }^{32}$ Dice el rey: "Los cuales premios, porque se den con toda rectitud y justicia al que mejor los meresciere, señalo por jueces a vos, reverendo arzobispo [de Toledo, Juliano], y a Giraldo, arzobispo de Cardona, y juntamente al conde Eurigo, y a Segismundo, duque de Cantabria, delegando como os delego a todos cuatro juntos y no al uno sin plenaria jurisdicción para determinar esta contienda, por ser como sois, personas de ciencia y conciencia y de quien yo confío lo determinaréis con gran retitud y sin parcialidad ni agravio de ninguna de las partes" (f. 6).

33 En realidad, el proyecto completo incorpora a treinta caballeros: "Y luego nombró a Ilderico, conde de Nemes, y el segundo, Desiderio, un caballero muy principal que le servía de copa; y el tercero, Severino, otro de los grandes de este reino. Y así señaló hasta treinta caballeros de los que con él iban, a los cuales tenía por más hábiles y de mayor entendimiento, 
se exculpa en un exordio ante el rey por su falta de pericia narrativa ${ }^{34}$.

Tras la narración de cada cuento intervienen siempre el rey, uno de los jueces y el siguiente narrador. En cinco de los relatos $^{35}$ el narrador del marco confirma el gusto que ha recibido el rey oyendo el cuento o lo que alabaron todos su invención. Así ocurre, por ejemplo, tras el primero: "Contento rescibió el rey de oír las cautelas que los cuatro soldados huyeron para huir la muerte y del galardón que dieron al carcelero..." (f. 27v); o en el segundo: "Muy loado fue por el rey, y no menos los que acompañándole iban, diciendo todos había sido muy gustoso y sustancial" (f. 47v); y en el quinto: "Mucho gustó al rey de las salidas que el obispo y fraile hallaron para los afrentosos lazos que armados les estaban..." (f. 124v).

Las palabras del monarca son siempre aplicaciones morales del tema del cuento a la vida actual. Por ejemplo, en el cuento primero dice: "Los jueces que quisieren hacer cosas de derecho hallasen quién ansí supiese obviar sus temeridades como estos soldados las enviaron, no llegarían tantas veces sus injustos rigores a efeto" (f. 27v). A continuación, uno de los jueces confirma los asertos reales ${ }^{36}$, produciéndose a veces una nueva intervención del rey. Así es el caso del cuento cuarto ("Sí mostraron, dijo el rey, y cierto, tales mujeres merecían tales maridos y tales

mandándoles que por la orden que los había nombrado fuese cada uno contando su cuento" (f. 6).

34 A modo de ejemplo transcribo la captatio benevolentiae de Ilderico: "Verdaderamente me será, noble príncipe y magnánimo señor, trabajosa y muy difícil de tratar cosa para mí tan nueva e inusitada y aun temerosa de emprender, por la sospecha que tengo de no poder cumplir con lo que a vuestra real presencia se debe y de ser por defetuoso notado de los presentes perlados y caballeros que en su servicio van, los cuales fácilmente conocerán mil faltas por ser como son tan doctos y experimentados en letras y armas y otros cualesquier virtuosos ejercicios, por lo cual quisiera mucho escusarme de ofender con mi insuficiencia a vuestro real merecimiento, mas pues vuestra alteza ha sido servido hacer la primera merced en querer rescebir de mí el primer servicio, yo diré lo que supiere, como supiere, para cumplir su real mandato y gozar del gran favor que sin le yo merecer se me hace" (f. 7).

35 En los cuentos 1, 2, 5, 9 y 10.

36 También en el cuento primero, donde se dice: "Por tanto, sería muy bien, dijo el buen arzobispo Juliano, que los reyes pongan en sus estados y pues los jueces de quien se tenga crédito administraran justicia y en esto tuviesen espicial cuidado de informarse, porque si los jueces no tienen el celo que deben muchos serían por año los agravios y desatinos que harán en deservicio de Dios y daño del prójimo" (ff. 27v-28). 
maridos tales mujeres", f. 104v), el 5 ("Bien lo creo", dijo el rey riendo) o el 10:

Vos, duque, dijo el rey, sois amigo de brevedad y las cosas del amor requieren mucha fe mas porque suelen ser largas sus esperanzas y no poco penosas, por lo cual tengo yo por avisado a los que huyen de sus lazos y procuran escusarse de semejantes pleitos y contiendas que acarrean perdición para las haciendas, detrimentos para las vidas y, lo que peor es, desasosiego para los espíritus y peligros para las ánimas (f. 271v).

Acto seguido, se da paso al nuevo narrador. A veces toma la palabra el narrador del marco, como ocurre en la transición desde el Fundamento al cuento primero; otra vez, en el segundo, lo anuncia el juez correspondiente; y las más de las ocasiones, en fin, es el propio rey el que pregunta a quién le toca el turno de intervención o le invita a que cuente, como en los cuentos $1,3,4,5,8,9^{37}$. En el sexto y séptimo cuentos, por último, el narrador inicia su discurso por su propia voluntad.

Por lo demás, en varios de estos engarces contextuales el narrador global introduce algunas marcas temporales que nos indican que las historias siempre se narran en el camino. También puede deducirse que el tiempo en que transcurre esta primera parte es de, por lo menos, una semana. Así, por ejemplo, tras el cuento 3 se dice: "Otro día el rey..." (f. 83v). Y después del 7, “...llegaron a un lugar donde el rey reposó aquella noche y otro día a la hora acostumbrada tornó a su camino" (f. 189v). O en el 8 se precisa: “...se hallaron junto a un pueblo donde al

37 Cuento 1: "Y acabando el obispo estas palabras, se alargó a la litera Desiderio, que era el segundo de los nombrados y viéndole el rey junto a sí le dijo: «Ea, Desiderio, decí vuestro cuento y mirá que ha de ser bueno para llevar el premio»" (f. 28); cuento 3: "Otro día el rey, preguntando quién era el siguiente nombrado, lo cual oyendo Ramiro, que era el cuarto de los nombrados, se llegó al rey y dijo estas palabras" (ff. 283v-284); cuento 4: "Dichas estas palabras, se llegó Ramiro, que era él que tras Severino se seguía, al cual el rey dijo: «Ea, Ramiro, mira cómo os habéis menester levantaros sois sobre los estribos para llegar al pasado»" (f. 104v); cuento 5: "Y luego mandó a Ricaredo, que era el que conforme al nombramiento sucedía, dijese su cuento, el cual, acercándose al rey, comenzó con las siguientes palabras" (f. 124v); cuento 8: "...y así mando que el que se siguía conforme al nombramiento dijese el cuento, el cual que era Leovigildo" (ff. 235-235v); cuento 9: "En fin, quien al demonio sirve, dijo el rey, si os permite sea por el mismo demonio engañado y traído a términos de confusión y afrenta venga Altidio que creo es el décimo de los nombrados" (ff. 255v-256). 
rey se hizo un solemne recibimiento y habiendo holgado allí dos días, en los cuales se le hicieron muchas fiestas, al tercero se partió" (f. 235). En fin, como escueto remate de la cornice, el narrador concluye, después de la intervención del caballero y el rey, con la idea de cerrar la primera parte: "Diciendo estas palabras llegó el rey a un lugar donde tenían hecho el aposento para la noche y se quedó allí hasta el día siguiente" (f. 271).

Está claro que la estructura de la obra ${ }^{38}$ proviene del modelo boccacciano. Lo muestra la sola división en tres décadas de cuentos. Esta secuenciación en varias partes integradas por diez novelas se extiende desde Boccaccio (recuérdese un total de cien novelas) al Novellino de Masuccio Salernitano, que establece cinco secciones; Margarita de Navarra, que divide el Heptameron en siete o Giraldi Cinthio en diez deca sus Hecatommithi. Ahora bien, el número de treinta novelas también conoce dos formulaciones renacentistas. Por un lado, Le cene de Anton Francesco Grazzini (il Lasca) ${ }^{39}$ y, por otro, Le piacevoli e amorose notti dei novizi, de Pietro Fortini ${ }^{40}$, dividida en tres jornadas con diez novelas cada una. Las primeras novelas quedaron manuscritas hasta 1756, pero las de Fortini se editaron en 1555, por lo que fácilmente pudo conocerlas Salazar ${ }^{41}$.

A pesar de todo, la temporalidad del marco, emplazado en la alta Edad Media, y los personajes que intervienen en él, el rey y sus cortesanos, se diferencian bastante de los esquemas italianos $^{42}$. La figura del rey como eje de la narración y las de sus consejeros y caballeros, agasajándolo en sus pretensiones y deseos, se parece más a los modelos enunciativos de las colecciones castellanas medievales ${ }^{43}$, tales como el Sendebar, el Calila

38 Para el panorama europeo siguen siendo válidos Wolfram Krömer, Formas de la narración breve en las literaturas románicas hasta 1700, Gredos, Madrid, 1970 y Walter Pabst, La novela corta en la teoría y en la creación literaria, Gredos, Madrid, 1972.

39 Anton Francesco Grazzini, Le cene, ed. R. Bruscagli, Salerno, Roma, 1976.

40 Véase la ed. de A. Mauriello, Salerno, Roma, 1995.

${ }^{41}$ La edición de sus dos primeros libros en Nápoles, así como el tratamiento de diversos asuntos históricos, hace suponer una estancia italiana de Salazar, quizá bajo el auspicio de don Pedro de Toledo.

${ }^{42}$ Más proclives al recreo o la fiesta cortesana.

43 Téngase en cuenta el clásico libro de María Jesús Lacarra, Cuentística medieval en España: los orígenes, Universidad, Zaragoza, 1979, y su antología, Cuento y novela corta en España, Crítica, Barcelona, 1999. Además, CARmeN Hernández Valcárcel, El cuento medieval español. Revisión crítica y antología, Universidad, Murcia, 2002. 
e incluso Los castigos e documentos para bien vivir ordenados por rey don Sancho IVy El conde Lucanor ${ }^{44}$. Para la pervivencia renacentista de tales modelos -los únicos marcos narrativos existentes hasta Salazar ${ }^{45}$-, hay que tener en cuenta la enorme proyección editorial de estas colecciones a lo largo del siglo xvi. Y es que la versión occidental del Calila (el Exemplario sobre los engaños y peligros del mundo) obtiene más de una docena de ediciones hasta $1547^{46}$ y la traducción del Sendebar también se edita media docena de veces, por medio, principalmente, del Libro de los siete sabios de Roma $(1510,1530,1538,1583,1595)^{47}$ y de la Historia lastimera del príncipe Erasto $(1573)^{48}$. Precisamente, la estructura de la colección de Salazar guarda ciertas concomitancias, al margen, desde luego, de la disparidad de contenidos, con el esquema marco de la versión occidental del Sendebar, donde los siete sabios narradores cuentan casos al emperador, narraciones de las cuales comentan, tanto unos como otro, cuestiones a propósito de la situación.

Por otro lado, aunque no existe una relación temática entre el marco y los diez cuentos, el narrador de turno se encarga de implicarlos de algún modo con el rey, caracterizando a éste como sucesor del monarca que se menciona para ubicar el arranque temporal en determinados casos. Así ocurre en el $1^{\circ}$ ("Acabada la guerra que en las Galias tuvo el rey Bamba, predecesor de vuestra alteza, etc., etc.", f. 7v) y en el $2^{\circ}$ ("Reinando en estos reinos el rey Sisebuto, predecesor de vuestra alteza...", f. 29). $\mathrm{O}$ con una variante, en el $3^{\circ}$ ("Felisbiano, el primero Papa que hubo de este nombre, ya vuestra alteza sabrá que, antes que la pontifical monarquía le fuese dada", f. 44v). En efecto, se trata

44 Sendebar, ed. M.J. Lacarra, Cátedra, Madrid, 2005; Calila e Dimna, eds. J.M. Cacho Blecua y M.J. Lacarra, Castalia, Madrid, 1984; Don JuAN Manuel, El conde Lucanor, ed. G. Serés, Crítica, Barcelona, 1994. Ahora también, M. Jesús Lacarra, Don Juan Manuel, Síntesis, Madrid, 2006.

45 Véase supra.

${ }^{46}$ Ahora podemos manejar una ed. dirigida por Marta Haro Cortés, Universidad, Valencia, 2007. Se editó conjuntamente con el Ysopete historiado, al menos en 1541, 1546, 1550 y 1621.

47 Contamos con la ed. de A. González Palencia, Versiones castellanas del Sendebar, CSIC, Madrid, 1946.

48 Véase Pedro Hurtado de la Vera, Historia lastimera del príncipe Erasto, eds. A.J. Farell y G. Meter Andrachuk, Universidad, Salamanca, 1996. Muy interesante es esta versión puesto que integra cuatro cuentos nuevos procedentes de la novelística italiana. Bien sabido es que El conde Lucanor fue impreso por primera vez en 1575 por parte de Argote de Molina. 
de un recurso para hilvanar los cuentos con el encuadre, que parece olvidársele al autor a partir de este momento.

\section{LOS GÉNEROS DE LAS NOVELAS}

En la Dedicatoria, Salazar establece perfectamente la doble naturaleza temática de sus novelas, unas de ellas, según define él mismo, "invenciones amorosas", y otras, de "materias de donaire e sal" ${ }^{49}$. A esta categoría segunda, más o menos burlesca, o por mejor decir, de carácter no amoroso, por contraposición a las primeras, pertenecen las novelas $1,2,5,9$ y $10^{50}$, o sea, la mitad de los cuentos. De este grupo, a su vez, las novelas 1 y 10 pueden definirse como dos casos legales, o juicios en toda regla, lo cual podría no tratarse de una mera casualidad, sino de un modo de subrayar la importancia de los aspectos jurídicos a lo largo de la colección, puesto que en gran medida, el cuento segundo también entraña un problema forense ${ }^{51}$.

El primer cuento (De cierta cuestión que tuvieron con unos gentiles hombres cuatro soldados que de la guerra venian ${ }^{52}$ parece tener la pretensión última de ridiculizar el sistema legal, en la figura de un juez y un carcelero -tema recurrente de la sátira del Siglo de Oro $^{53}-$, a través de un suceso bastante intrascendente. Cua-

49 "E así, puesto que en esta obra haya algunas invenciones amorosas y otras materias de donaire e sal, procuré yo escribir por términos tan moderados y palabras tan medidas que espero en Nuestro Señor no se notará en ellas alguno de los dichos escesos" (f. 3v).

50 De los que parece querer confirmar su calidad.

51 Sobre cuestiones y decisiones jurídicas, así como en adelante para diversos paralelos temáticos, véase D.P. Rotunda, Motif-index of the Italian novella in prose, Indiana University, Bloomington, 1942, J1170. Téngase en cuenta, además, la Gesta Romanorum, 29 (eds. V. de la Torre y J. Lozano Escribano, Akal, Madrid, 2004, p. 119, n. 157) para más información sobre el tema de la reprensión de los malos jueces.

${ }^{52}$ Concomitancias del motivo pueden verse en Rotunda, J1289.13. Cita las Facezie, 50 y 91 de Ludovico Carbone.

${ }^{53}$ Sobre las decisiones injustas de un juez versa, por ejemplo, la Patraña 6 de Joan Timoneda (El patrañuelo, ed. P. Cuartero Sancho, Espasa, Madrid, 1990, pp. 103-107). Véase, además, la novela 196 de Franco Sacchetti (Messer Rubaconte Podestà di Firenzedà quattro bellie nuovi iudici in favore di Begnai, en Il Trecentonovelle, ed. D. Puccini, UTET, Torino, 2004, pp. 560-563). En el Decamerón, la antipatía a los jueces y el sistema jurídico resulta manifiesta, por ejemplo, en las novelas II, 10 y VIII, 5. También Melchor de Santa Cruz dedica una sección a los jueces en la Floresta española, IV, 1 (eds. M.P. Cuartero y M. Chevalier, Crítica, Barcelona, 1997, pp. 105-109). 
tro soldados (Alderín, Acridano, Monsedro y Garbeo) llegan a la ciudad de Burgos, acabada la guerra de las Galias, y, estando en la posada donde van a pernoctar, arriban tres gentiles hombres, con sus criados, con el deseo de ocupar por la fuerza su habitación. La disputa termina con el asesinato de dos de los caballeros; los soldados, quienes inicialmente se recogen a sagrado, al final deciden entregarse a la justicia, urdiendo -a instancia de Garbeo, quien sabe de leyes-, la estratagema de acusarse mutuamente para confundir -puesto que sólo dos son los culpables. Tras varios interrogatorios infructuosos y otras tantas pesquisas invalidadas, el juez aplica un procedimiento de presunciones que lo lleva a confirmar la culpabilidad de Garbeo y Monsedro. En este punto comienza una segunda secuencia del relato -más afín a los estereotipos folclóricos-, que se centra en el intento de los soldados por engañar al carcelero con el señuelo de un tesoro escondido ${ }^{54}$, del que prometen hacerlo partícipe si los ayuda a escapar. Lo único que consigue el carcelero es salir molido a palos.

El cuento 10 (De cierto pleito y contienda que hubo entre tres hermosas ninfas y cómo fueron ante la diosa Venus que las juzgase y las sentencias que sobre ello se dieron) podría definirse como una suerte de juicio de amor, recreación evidente del Juicio de Paris ${ }^{55}$ y en cierta medida similar a las quaestiones de amor tan presentes en la ficción sentimental del siglo Xv -sobre todo a partir del libro 4 del Filocolo ${ }^{56}$. Hipólito, hijo de Teseo y Deyanira, reyes de Boecia, es un gran amante de la caza; un día se desvía de su camino siguiendo a un ciervo y va a parar a un lugar ameno donde oye tres voces que cantan. Descubre que son tres ninfas (Tetis, Siriga y Epis), las cuales se enamoran de él de repente. Para mostrar quién lo ama más y alcanzar su amor en exclusividad deciden contender entre ellas. Otro día, ellas le comunican al príncipe que desean que haga de juez para dictaminar al respecto, pero él prefiere que lo echen a suertes. Las ninfas, sin embargo, acuerdan que el pleito quede en manos de Venus. Entonces

${ }^{54}$ Puede verse, al respecto, GIRALDI, Hecatommithi, I, 4 (Un giudeo, in habito di prete, dà a intenderead uno avaro di volergli far ritrovare un thesoro et poscia schernitolo lascia, ed. Venezia, 1566, pp. 113 ss.). Esta novela se tradujo al español: Primera parte de las cien novelas, Toledo, 1590, ff. 143-152. Véase Sebastián Mey, Fabulario, 26.

${ }^{55}$ La fábula se recrea en Apuleyo, X, 6.

${ }^{56}$ Los capítulos 17 a 72 son en cierta medida una cornice previa al Decamerón. 
se produce el juicio ante tres jueces que atienden las alegaciones de las ninfas, pero que no logran ponerse de acuerdo, por lo que terminan dictando sentencias diversas, lo que conlleva una irresolución del caso ${ }^{57}$.

Por su parte, el cuento segundo (De cómo un mozo no quiso fiar de su padre cierta hacienda que le daban y la confió de un amigo suyo $)^{58}$ plantea el problema jurídico del derecho sucesorio ${ }^{59}$ y de la patria potestad, a partir del motivo del amigo desleal ${ }^{60}$. Andronio, que no tiene hijos, decide dejar como heredero a su sobrino Pirro. Para salir del dominio paternal, éste pide a su tío que instituya como sucesor a su amigo Magón. Pirro confía plenamente, a pesar de las reticencias del tío, en que Magón le restituirá los bienes cuando se los pida. Pero esto no ocurre así, y a Pirro no le queda otra solución que acudir a la justicia, por más que una mala gestión procesal conduzca a que el amigo gane la sentencia. La suerte de Magón, sin embargo, cambia radicalmente y se ve envuelto en un engaño (el tema del burlador bur$l a d o$ ), que lo lleva a perder toda la hacienda. Por el contrario, Pirro, luego de diversos avatares, recupera sus bienes primigenios y, ya rico, encuentra a Magón pidiendo limosna y rechazado de todos por haberse infectado de lepra ${ }^{61}$-signo fatal del

57 Compárese, además, con Núñez de Reinoso, Los amores de Clareo y Florisea. En el cap. 11, que se desarrolla en la Ínsula de la Vida, tiene lugar un juicio paralelo (ed. M.A. Teijeiro Fuentes, UNEX, Cáceres, s.a., p. 105).

58 Alguna concomitancia argumental mantiene con RoTUNDA, H1558.7. Sobre el tema del poder del dinero y la vuelta de pródigo a avaro puede tenerse en cuenta Straparola, Le piacevoli notte, XIII, 13 (Pietro Rizzato uomo prodigo impoverisse e trovato un tesoro diventa avaro, en Le piacevoli notte, ed. P. Pirovano, Salerno, Roma, 2000, t. 2, pp. 786 ss.), con amplia trayectoria, por ejemplo, en Morlini, Poggio, Facezie, IV o Giraldi, IX, 8.

${ }^{59}$ Sobre la última voluntad paterna, véase MorLINI, novella 27 (De filiis qui post obitum patris eius ultimm voluntatem exequi noluere, en Novelle e favole, ed. G. Villani, Salerno, Roma, 1983, pp. 132 ss.). Sobre testamentos, por ejemplo, Straparola, Notte, XII, 4 (D'alcuni figliuoli che non volsero essequire il testamento del padre loro, ed. cit., p. 719), con el mismo argumento.

60 Podría ser una variante del tema de los dos amigos, pero sin el elemento amoroso. Véase Decamerón, X, 8 y Gesta Romanorum, 171, etc. Además, por supuesto, Cervantes, El curioso impertinente. Pero, sobre todo, el tema de la prueba del amigo, con la inclusión del motivo del burlador burlado, aparece en los Gesta romanorum, 129 y JuAn Manuel, ejemplo 48. Añádase, además, Gesta romanorum, 118; Pedro Alfoso, Disciplina clericalis, 15 (Simancas ediciones, Palencia, 2005); Decamerón, VIII, 10 o incluso Mey, Fabulario, 8.

${ }^{61}$ Temas aledaños en Rotunda, F955.1. Además, la Historia del Gran Soldán (Gracián Dantisco, El Galateo español, ed. cit., pp. 156-164). Sobre la lepra, Gesta romanorum, 151. 
castigo divino por su mal comportamiento. A pesar de todo, lo lleva a su casa, lo cura y reparte con él su patrimonio. Así pues, la bondad de uno hace que recupere todo lo perdido; mientras que la fortuna adversa castiga al malvado ${ }^{62}$.

Los otros dos cuentos del conjunto, el quinto y el noveno, sí pueden calificarse sin ambages como abiertamente burlescos. El 5 (De cómo un caballero casó con una señora, la cual, después dél muerto fue requerida de amores por dos personas de much a auturidad y lo que con ellos sucedió) se asemeja muchísimo a los cuentos del Decamerón, sobre todo al VIII, $4^{63}$, incluso por su emplazamiento italiano, y es el único que plantea una relación de tipo erótico, fuera del ámbito conyugal. La situación inicial parte del matrimonio dispar de un viejo impotente ${ }^{64}$ con Faustina, cuyo ardor acaba con su vida. Desde que Faustina se queda viuda la sirve un adelantado, pero también tiene como pretendientes a dos hombres de iglesia, un obispo y un fraile confesor ${ }^{65}$. Faustina y su criada, Camila, piensan dar un escarmiento a los dos enamorados. En la cita acordada, con el fin de descubrirlos ante el adelantado, meten al obispo en un aposento y también encierran al fraile. Sin embargo, ambos inventan una rocambolesca historia con el fin de exculparse, historia en la que Faustina queda mal parada. El caso es que el adelantado les cree y la mujer pasa de burladora a burlada.

Sin duda, el cuento más divertido de la serie es el noveno ${ }^{66}$ (De ciertas burlas que hicieron unos estudiantes una noche a ciertas per-

62 Compárese con Giraldi, Hecatommithi, VII, 7 (Sergio di ricco che prima era, per lo suo sconcio spender et consumare, è ridotto in pouertà, morde Marcello, che temperadamente spende, et egli con pronta risposta lo trasige, ed. cit., p. 210).

${ }^{63}$ El párroco de Fiésole ama a una señora viuda; ella no le ama, y creyendo acostarse con ella, se acuesta con una criada suya, y los hermanos de la señora hacen que su obispo le sorprenda (ed. cit., pp. 861 ss.).

${ }^{64}$ Tema recurrente que aparece desarrollado de modo muy gráfico en el Decamerón, II, 10.

${ }^{65}$ En Morlini, novella, 72, la mujer engaña, por ejemplo, a tres religiosos (De stipatoribus regis Ferdinandi qui demones, ut Picus ederent, emulati sunt, ed. cit., p. 316).

${ }^{66}$ Se subraya oportunamente: "De ganas rió el rey de oír las burlas que los estudiantes habían hecho con el cuerpo muerto..." (f. 255v). Véase, en paralelo, Fortini, Le piacevoli e amorose notti dei novizi, I, 1 (Come certi gioveni dano ad intendá a un villano che due capretti sono um-paio di capón; e dipoi, alfine, li fanno crédare che sia morto, e il fratello cor un bastone lo torna vivo, ed. A. Mauriello, Salerno, Roma, 1995, p. 699). De estudiantes trata además el cuento I, 5 (Come certi scolari tolsero a un dottore una coscia di carne salata e a un altro un grosso paio di capón. A lloro fu tolta la coscia, i caponi e, in compagnia di 
sonas diversas), que parece ser el que más influencias tiene de la literatura popular -incluso en su construcción, basada en sucesivas viñetas. En cierta medida, por el ambiente estudiantil y prostibulario -y la galería de personajes y tipos que aparecen-, podría sostenerse que guarda ciertas similitudes con el ambiente picaresco. En este relato se cuentan las burlas que unos estudiantes de derecho -residentes en un pupilaje de Mérida- hacen a varias personas utilizando el cuerpo muerto de un ahorcado disfrazado como si estuviera vivo. Se trata de que todos piensen, sobre todo la justicia -muy implicada a lo largo de la trama-, que ellos han sido los asesinos. El episodio más truculento se produce en la mancebía y hace intervenir a una prostituta y su rufián, pero tampoco se libran un confitero, un tabernero, un enamorado, un pobre o una vieja hechicera.

Así pues, en términos generales, se puede afirmar que estos cinco cuentos son los menos extensos de la primera parte, ya que tres de ellos $(2,5,10)$ constan de ocho secuencias narrativas, mientras que el 9 tiene once y el 1, doce. También tienen once y doce secuencias los cuentos 7 y 4 del otro grupo, mientras que el 3, 6 y 8 se componen de veintitrés, veintiuno ${ }^{67}$ y veinte segmentos, respectivamente. Este cómputo cuantitativo tal vez sirva para mostrar la importancia cualitativa de esta serie sobre la anterior.

En el cuento octavo (De cómo por la maldad de un traidor, un rey y un fiel vasallo suyo padecieron muchas fatigas y trabajos) la historia amorosa está muy supeditada a la trama principal, que se centra en un asunto de rencillas políticas, ubicado en la Grecia clásica, como el cuento 10. Varios temas y motivos se entrelazan en la novela. Por un lado, la oposición entre el vasallo leal, falsamente acusado ${ }^{68}$, y el desleal -que consigue, sin embargo, sus

quelli, Otto polli piú. E cosí rimascero li scolari scherniti e beffari, en ibid., p. 754). Y Sabadino degli Arienti, Le Porretane, 42 y 44 (ed. B. Basile, Salerno, Roma, 1977, pp. 361 y 369$)$.

67 Véase: "Algo largo ha sido el cuento, dijo el rey, pero a mí ningún fastidio me ha dado, porque cuando [me ha dado] la materia es apacible y gustosa y la relación se hace con buena gracia y estilo, aunque dure largo rato no molesta a los oídos" (f. 165). Este tipo de razonamientos sobre la extensión del relato aparece en Decamerón, por ejemplo, en III, 7-8: "Acabado el largo cuento de Emilia, que no había desagradado a nadie por su extensión..." (p. 431).

68 Véase, por ejemplo, GiRALDI, Hecatommithi, 4, 2 (Eugenio per la sua virtù diuien grande apresso il Rei di Napoli, è accusato al re di tradimento, con falsa testimonianza, etc., ed. cit., p. 353). 
malvadas pretensiones-; el rey convertido en mendigo frente al plebeyo hecho rey, etc. El detonante de la historia, sin embargo, es un problema de amores: Jerjes ${ }^{69}$, rey de Acaya, pide al de Lacedemonia que su hijo se case con su hermana, pero, ante su negativa, decide hacerle la guerra. Es entonces cuando deja a cargo del reino al caballero Patroclo, quien pronto recibe presiones de Palamides, declarado enemigo del rey, para que lo derroque del trono. Al ver que no logra convencerlo, Palamides lo acusa injustamente de traición, consiguiendo que Jerjes lo sentencie a muerte. A Patroclo no le queda otro remedio que huir con su mujer (Clitenestra) y sus dos hijas (Penélope y Fedra) hacia Atenas. A partir de aquí se enlaza la segunda trama: un despensero, que tiene cuentas pendientes con la familia, envía a unos amigos para que rapten a Penélope y la lleva a su casa como criada de su hija. En el camino se detienen en una venta a la que llega Agesilao, un joven estudiante ${ }^{70}$ que se enamora de Fedra. Agesilao pide ayuda al ventero para raptarla, éste le da un agua soporífera con la que aprovecha para robar a los huéspedes. Los problemas no acaban aquí, puesto que en el monte cinco salteadores despojan de todo ${ }^{71}$ a la infeliz pareja, que se ve obligada a llegar a pie a Atenas y pedir limosna. Finalmente, enferman, acuden a un hospital, donde se curan, y en él se quedan a ayudar a los internos. Entre tanto, Palamides ha sido nombrado gobernador y, en una progresiva estrategia de nepotismo, se alza con el trono de Corinto, mientras que Acaya se divide en siete reinos. El rey es apresado, escarnecido y desterrado. También se hospeda en la venta de marras, donde le ocurren varias penalidades, y finalmente llega a Atenas a internarse en el hospital donde está Patroclo, conocido ahora como Doroteo. Tras el reconocimiento, Patroclo aconseja al rey que se vayan a Boecia, donde es fama que reina un monarca muy justo que puede restituirlos en sus derechos, pero el rey actúa de modo contrario y los castiga. De cualquier modo, lo más sorprendente es que la reina, en realidad Fedra, reconoce a su padre e impide la pena de muerte. El caso es que su otrora raptor fue hecho rey por los boecianos, toda vez que el monar-

${ }^{69}$ Jerjes es protagonista, por ejemplo, en Sebastiano Erizzo, Le sei giornate, 27 (Polidamante, combatiendo contra l'essecito di Xerxe, è ferito in una coscia di una lancia; $e$, intesa la rotta di Xerxe, listamente si muore, ed. R. Bragantini, Salerno, Roma, 1977, p. 230). A partir de Valerio Máximo, IX, 12, 3.

70 Cierto paralelismo puede notarse con RotundA, H335.0.2.

71 Compárese con Decamerón, V, 3. 
ca antecesor murió sin descendencia. Sólo falta que Penélope se escape del despensero, para que una vez restituido, el rey Jerjes se case con ella.

También en un contexto regio ${ }^{72}$ se desarrolla el cuento 4 (De una famosa hazaña que una reina y una princesa su hija hicieron $y$ del dolor que por ello dos príncipes recibieron), que gira en torno al enfrentamiento de dos pretendientes por conseguir la mano de la princesa Deyanira ${ }^{73}$. Ésta es hija de la princesa Briseida y de Zaharán, hijo del rey de Turingia. Cuando el rey convoca a un torneo en Augusta, para celebrar una conquista de su padre, los reyes de Austria (Narcindo) y de Baviera (Argilao), que han acudido a la cita, se enamoran de la princesa. Argilao, que manda embajadores a pedir la mano de Deyanira, ante la negativa de los padres decide tomarla a la fuerza asediando la ciudad ${ }^{74}$. Es entonces cuando Briseida, para escapar de una muerte segura, manda elaborar un agua venenosa ${ }^{75}$, de la que beben ella misma y su hija. Narcindo, el otro pretendiente, no se queda al margen y ayuda al rey en su contienda; a la postre, ambos creen que su lucha ha sido en vano, pues suponen que las mujeres han muerto, y deciden quitarse la vida. Ahora bien, las muertes han sido sólo un simulacro, porque en realidad el agua únicamente tiene un efecto adormecedor. Una vez que los reyes despiertan y comprueban el gran amor que Narcindo siente por su hija -que lo ha llevado a autoinmolarse-, resuelven que se casen. Este argumento, mucho más lineal que el anterior, guarda estrechas similitudes con algunas de las tramas sentimentales de las que forman parte la oposición de dos rivales que se disputan a la amada en un torneo, y el descubrimiento del enamorado que siente un verdadero amor. En este caso, el elemento que permite esta suerte de ordalía es el agua venenosa, un motivo temático recurrente.

Por último, las novelas 6 y 7 mantienen bastantes conco-

72 Ese ámbito es el de la mitad de los cuentos: así el 2, quizás el 3, 4, 6 y 8.

73 Compárese con Giraldi, Hecatommithi, X, 2 (ed. cit., p. 380).

74 Cf. Timoneda, Patraña 5.

75 Hay relación con el motivo de Rotunda, K1852. Véase Patrañuelo, 20. También GIRALdi, Hecatommithi, III, 5 (Consalvo, pigliara Agata per moglie, s'innamora di una meretrice, si delibera di avelenare Agata. Uno scolare gli dà, in vece di veleno, polvere da far dormire..., ed. cit., p. 302); SЕRсамвi, Il novelliere, XXII, 2; 42; Girolamo Parabosco, I diporti, II, 12; Sansovino, Cento novelle scelte, Venezia, 1556, IX, 3; Giovanni Fiorentino, Il Pecorone, 23. La fuente primigenia ha de ser Apuleyo, XI, X, 2-12. En relación con esto, véase Decamerón, IV, 10. 
mitancias entre sí y yo me atrevería a decir que acaso podrían caracterizarse como pequeños relatos protobizantinos, quizás de los primeros en la literatura española ${ }^{76}$-salvando la Quexa y aviso contra amor de Juan Segura (1548) o el Clareo y Florisea de Núñez de Reinoso (1552) ${ }^{77}$. En el cuento 6 (De cómo una princesa italiana fue cautiva por un cosario africano y ella cativó con su hermosura un gentil mozo español que padeció por ella muchas fatigas ${ }^{78}$ ), en medio de una tormenta, el corsario Tirmo rapta ${ }^{79}$ a la princesa Oridiana de Nápoles, la lleva a África y la vende como esclava a Vedino ${ }^{80}$-un mercader rico casado ya con cuatro mujeres-, cuya pretensión es enamorar a Oridiana y hacerla renegar de la religión cristiana ${ }^{81}$. En esto, llega a África, para hacer negocios,

${ }^{76}$ El panorama básico para el corpus y la poética del relato de tipo bizantino lo constituye Javier GonzÁlez Rovira, La novela bizantina en la Edad de Oro, Gredos, Madrid, 1996.

77 Véase, para este tipo de estructura bizantina, el Decamerón, II, 4; II, 7; IV, 3 y 4; V, 2.

${ }^{78}$ Este relato parece desarrollarse en la España visigótica, como el 1 y el 2, hecho que lleva a pensar que la cronología y el espacio del marco interfieren en los de las novelas, situándolas en un período temporal alejado de la contemporaneidad, a excepción acaso del cuento 9, que sí se desarrolla en la Mérida del Siglo de Oro.

${ }^{79}$ Para este tema eminentemente bizantino, véase Rotunda, 12.1 y 2. Además, Decamerón, II, 10 y II, 4; DEgLi ARIEnti, Le porretane, 59 (Eliseo di Bologini, partendose dal re Ladislao fu preso da pirata e a uno mercadante moro venduto; e conosciuto poi omo de gran virtú, divenne carissimo al signore de quella terra dove fu conducto. E morendo poi el signore, Eliseo per virtú del suo ingegno doppo alcuno affani ne diventò signore, ed. cit., p. 522); GIRALDI, II, 6; VIII, 6; Sansovino, Cento novelle scelte, Venezia, 1556, III, 5 y 6 . Además, Cervantes, El amante liberal. Véase, asimismo, Ascanio Mori, Novelle, 1.

80 Sobre la aparición del mercado de esclavos, véase Rotunda, 61. Cf., además, Arienti, Le porretane, 59; Firenzuola, Novelle, 1; Masuccio SalerNitANo, Il Novellino, 48 (Un figliolo del re de Tunisi è preso da corsali e venduto a Pisa, il patrone li dona libertà, deven re: el patrone li recapita in mano, e li dà la sorellaper moglie, e con lei ricchissimo nel remanda a Pisa, eds. L. Settembrini y S.S. Nigro, BUR, Milano, 2000, p. 537); Parabosco, I Diporti, II, 13; Sansovino, VIII, 6; Ascanio Mori, Novelle, 1. Sobre el tema de la huída de la esclavitud, véase Rotunda, 211.4. Por ejemplo, M. Bandello, Novelle, III, 68 (Messer Marco Antonio Cavazza in meno di sue sttimane casca in varre strani accidenti, e, fatto sachiavi di mori, vien liberato con sua buona fortuna, ed. F. Flora, Mondadori, Milano, 1966, t. 2, p. 605); ErIzzo, Le sei giornate, I, 1; I, 6 y II, 9; Giraldi, II, 6 y X, 4; Masuccio, Il Novellino, 39. Cf. Decamerón, II, 6 y 7; IV, 3; V, 3.

${ }_{81}$ Así pues, encontramos reflejado el tema del cautiverio en África antes de la Selva de aventuras de Contreras (1565). Véase, por ejemplo, SAntiago Fernández Mosouera, "Introducción a las narraciones bizantinas del siglo xvi: el Clareo de Reinoso y la Selva de Contreras", Criticón, 71 (1997), 65-92. 
un joven español llamado Paulo, y entra en contacto con Vedino, quien lo invita a comer a su casa, donde conoce a Oridiana y se enamora de ella. Oridiana había dicho a su amo que era francesa y que su nombre era Archiopina. Paulo resuelve rescatarla -otro de los elementos integrantes de la ficción griega-, y para ello ofrece a cambio toda su mercancía al ambicioso Vedino. Entonces, emprenden el viaje a España y, para defenderse del acoso de Paulo, la doncella afirma que ha hecho votos de castidad. Ya en Barcelona, Paulo la lleva a casa de su tía Orosia, a quien pide que la acoja y proteja. La casualidad hace que el rey Teodosio de España necesite de la ayuda del rey de Nápoles, padre de Oridiana, para combatir a los cosarios africanos. Manda a España sus galeras, donde va el capitán Arbicio, muy conocido de la princesa puesto que servía a su madre. Con la ayuda de su criada, Orpina, y de un compañero, logra rescatar a las dos mujeres y conducirlas a Nápoles. El rey manda de nuevo a Arbicio a Barcelona para que traiga a Paulo y Orosia con el ánimo de poder darles una merecida recompensa. Paulo, por su parte, determina ir a buscar a Archiopina y, tras su partida, la madre (Agrina) cae enferma. En trance de muerte, la mujer confiesa a un fraile que Paulo es el hijo segundo del rey Teodosio y que en realidad se llama Narses. Su verdadero hijo fue suplantado por él para poder criarlo ${ }^{82}$. Todos conocen finalmente la verdad al hacer testamento público de su engaño.

En Nápoles, a la sazón, Orosia va consiguiendo que Oridiana se enamore poco a poco de Narses, quien la busca infructuosamente en Francia. Pasa entonces a Italia y, después de dos años de camino -en los que pide limosna-, se hospeda en una posada donde Jaciso, un huésped que se conduele de sus lamentos, le ofrece protección y lo lleva a Nápoles, donde lo invita a una fiesta en el palacio real. Ahí se producirá el encuentro con Oridiana y el reconocimiento, asimismo, de Orpina y su tía Orosia -las cuales, a su vez, lo identificarán un día que canta y tañe sus instrumentos ${ }^{83}$. Al ser público y notorio en la corte que es hijo de rey, puede pedir en matrimonio a la princesa y casarse finalmente con ella, como ocurre.

${ }^{82}$ El trastrueque de hijos aparece, por ejemplo, en Giraldi, II, 9. Es motivo tradicional: Anti Aarne y Stith Thompson, Los tipos del cuento folklórico. Una clasificación, STASF, Helsinki, 1995, 920.

${ }^{83}$ Véase Rotunda, H79.3. Por ejemplo, Bandello, Novelle, II, 54 (Lione Aquilino con astucia tanto fa que possiede la donna amata, ove intervengono diversi accidenti, ed. cit., p. 196). 
En el cuento séptimo (De cómo un caballero español enamorado de una dama extrajera que vio en cierta romería se fue a la servir y del suceso que en sus amores tuvo) la acción principia en Hungría. Alicandra está enferma y promete ir de romería a Santiago con su marido Lisandro y su hija Linesdaia. Un caballero español, llamado Otenrico, también se encuentra allí haciendo votos con su madre Teodora. Se enamora de Alicandra cuando la ve y, llegado el momento de la partida, se desmaya delante de la familia. Ellos, sin embargo, vuelven a Zarra y Otenrico permanece enfermo de amor durante ocho meses. Una vez restablecido, decide embarcarse para Zarra y, bajo la identidad de Ramiro, entra al servicio de Artacel, hermano de Linesdaia, para estar más cerca de ella. Linesdaia se va aficionando a él, tanto, que acepta que la rapte para llevarla a España, aunque, eso sí, con la condición de desposarse y no consumar el matrimonio hasta que lleguen a León. A la altura de Almería, sin embargo, aparecen dos corsarios que, a pesar de la resistencia de Otenrico, los apresan. Uno se llama Faramón y el otro Androgeo. Este último intenta violar a Linesdaia, pero una tormenta providencial lo impide. En el estrecho de Gibraltar, un capitán de la Coruña, llamado Jasdricán, endereza hacia el barco maltrecho. Salva a la doncella y la encomienda como criada de su mujer. Otro barco gallego se topa con el otro corsario -se trata de Frondisio, amigo de Jasdricán-, quien los salva a todos y lleva a Otenrico a la Coruña. Un día, Otenrico va a casa de Frondisio con su amigo y Linesdaia lo reconoce. Esta anagnórisis será el acicate para el matrimonio final.

Tras los resúmenes de las dos últimas novelas, salen a la luz una serie de elementos comunes, todos caracteres definitorios del relato griego ${ }^{84}$. Aparecen los raptos marinos, la esclavitud o servidumbre inesperada, los rescates, el cambio de nombre, el peregrinaje, la mendicidad forzada, la suplantación de personalidad, los embates lascivos, los reconocimientos varios y, por supuesto, como cierre de las historias, la nueva fórmula del amor casto y conyugal. Un happy end que sucedía también en los relatos 4 y 8 y que, asimismo, se convierte en el eje argumental de la novela 3 (De cómo una mora principal fue falsamente acusada de adulterio y lo que sobre ello sucedió).

84 Además del libro cit. de González Rovira, pueden verse: Miguel A. Teijeiro Fuentes, La novela bizantina española: apuntes para una revisión del género, Universidad, Extremadura, 1988 y Emilia Deffis de Calvo, Viajeros, peregrinos y enamorados. La novela española de peregrinación del siglo XVII, EUNSA, Pamplona, 1999. 
Ahora bien, muchos de estos rasgos bizantinos estaban ya presentes en el Decamerón o en los novelistas italianos posteriores, y puede ser ésa la vía por la que llegan a Salazar. Algunas de estas concomitancias -además de otros extremos-con los novellieri ya se han ido señalando, principalmente, en las notas a pie de página, a pesar de no ser esa identificación el objetivo principal de este artículo. Ese seguimiento de los modelos ocurre en otras colecciones de cuentos más o menos coetáneas -sobre todo en Timoneda o Tamariz ${ }^{85}$-, en las que gran parte de los relatos son recreaciones más o menos libres de novelas italianas ${ }^{86}$. Pero donde la influencia de un modelo previo parece tener una mayor proyección en la obra de Salazar es en este cuento tercero, donde se recrea la novela II, 44 de Bandello ${ }^{87}$ -sexta de las traducidas en la edición española ${ }^{88}$-, de la que más tarde Timoneda elaborará una versión en la Patraña 7 (1567) y Alonso de la Vega otra en La duquesa de la Rosa-editada por Timoneda en $1566^{89}$. Aquí la defensa de la fidelidad, a pesar de la impotencia del marido, será la causa del injusto castigo que puede llevar a la dama a la muerte. En efecto, Julia, hija del Papa Felisbiano, por imposición de éste se casa con Triburcio, hombre feo e impotente ${ }^{90}$. Su sobrino y heredero, Octavio, se enamora de ella, pero, a pesar de sus intentos, Julia lo rechaza. Simultá-

85 Véase Cristóbal de TAmariz, Novelas en verso, ed. D. McGrady, University of Virginia, 1974.

${ }^{86}$ En Timoneda hay reminiscencias de Boccaccio, Salernitano, Gesta romanorum, Bandello, Parabosco, Cintio, Sabadino degli Arienti, Giovanni Florentino, etc. En Tamariz, influencias de Salernitano, Straparola, Bandello, Giovanni Florentino, Boccaccio, etc.

${ }^{87}$ Ya Blecua adelantó que las considera muy en la línea de Bandello y no le faltaba razón. La novela en cuestión es Amore di don Giovanni di Mendoza e la duchessa di savoia, con varii e mirabili accidenti che vi intervegono, ed. cit., II, 112.

${ }^{88}$ Historias trágicas y ejemplares sacadas de las obras de Bandello Veronés, Salamanca, 1589: "De cómo una duquesa de Saboya fue acusada falsamente de adulterio por el conde de Pancaller su vasallo. Y cómo siendo condenada a muerte, fue librada por el combate de don Juan de Mendoza, caballero principal de España. Y cómo después de muchos sucesos se vinieron los dos a casar. Repártese en doce capítulos" (ff. 116-164v).

${ }^{89}$ Las tres famosísimas comedias de... Alonso de la Vega, Valencia, 1566, junto con Tolomea y Serafina. Las relaciones temáticas entre esas dos obras con el cuento de Salazar, así como las concomitancias y divergencias con el original italiano y la traducción española, serán objeto de un trabajo independiente, por lo que no me detengo aquí en prestarle mayor interés al asunto.

${ }^{90}$ Le da un joyel de dote. Compárese el motivo de la identificación por ornamento en Rotunda, H 90. Además, Patrañuelo, 5 y 11. 
neamente, dos españolas pasan por Roma en su peregrinaje hacia Tierra Santa. Las alabanzas que estas mujeres hacen de Severiano, duque de Cartagena, llegan a oídos de Julia y hacen que ella se enamore de él ${ }^{91}$. Julia decide acudir a una casa de oración, cerca de Milán, y, más tarde, se dispone a ir en peregrinación al santuario de Nuestra Señora de la Laguna, en España; la acompaña Octavio, quien la importuna de tal modo que Julia manda encadenarlo. El encuentro entre Julia y Severiano tiene lugar en España y, aunque ella no lo admite como amante, Octavio en venganza la acusa injustamente de adulterio ${ }^{92}$. Julia es encarcelada, a pesar de su inocencia y virginidad -puesto que con su marido no ha llegado a consumar el matrimonio. Allí, manda llamar a Severiano para que interceda por ella; si bien Severiano inicialmente pone una excusa, al final, disfrazado de fraile, la visita en prisión ${ }^{93}$. Cuando se están llevando a cabo los preparativos para la ejecución, Severiano desvela la calumnia. En ese tiempo muere Triburcio, dejando libre el camino para que la pareja pueda casarse.

\section{PARA HONESTAMENTE RECREARSE}

Por supuesto, la defensa del matrimonio como fin primordial de los amores no es más que una evidencia notable del principio moral que subyace a la colección de novelas. Ya se ha visto que incluso las pretensiones lascivas son finalmente reprimidas o castigadas y, salvo la viñeta de la prostituta y su rufián y, quizá, el argumento del relato quinto, todo en los cuentos converge hacia la castidad, obligatoria hasta el momento de la sanción matrimonial. Este componente didáctico no sólo se vislumbra o infiere de la lectura de los cuentos, a partir de las consecuencias que trae consigo la práctica de la justicia mal empleada o la deslealtad al amigo o al señor -por poner otros elementos de discusión ética aparte del tema amoroso-, sino que queda explícito en dos lugares muy concretos como programa literario. Sobre todo en la dedicatoria del autor y después en las intervenciones

91 El motivo del enamoramiento de oídas es de origen provenzal. En el Decamerón hay varios ejemplos: I, 5; II, 7; VII, 7.

${ }^{92}$ La mujer infamada como adúltera es motivo tradicional. Véase ANTI Aarne y Stith Thompson, Los tipos del cuento folklórico..., tipo 883a, motivo K2112.

${ }^{93}$ Para este disfraz, véase Giraldi, I, 4, por ejemplo. 
de los personajes del marco narrativo, cuando comentan el relato de turno.

La concepción que Salazar tiene del género es eminentemente didáctica y ello se observa en el término que aplica a las narraciones, a las que llama, además de cuentos o novelas, consejas, porque, dice: "antiguamente en Castilla llamaron consejas, por los buenos consejos y ejemplos que de ellos colegirse pueden" (f. 3). En efecto, la finalidad última que el autor otorga a sus relatos es de cariz didáctico, aunque por supuesto albergue asimismo un espacio para el componente deleitable, tal como se lo expone al rey, necesitado de expansión y recreo:

Y para sobrellevar tan pesados cargos como estos, conveniente, y aun nescesario, le es a tiempos honestamente recrearse, pues está claro que no se puede conservar la vida humana con el continuo trabajo. Y así mi fin principal ha sido ofrecer a V. M. esta lectura para alguna recreación de vuestro real entendimiento (ff. 3v-4).

Ese principio de honestamente recrearse resulta ser la clave, repetida en términos muy parecidos en otros muchos textos posteriores $^{94}$, de carácter ejemplar que explica el argumento de los cuentos. Y por eso las autoridades que aporta Salazar como precedentes en la creación novelesca pertenecen al ámbito religioso:

...el excelente doctor San Jerónimo, el cual en sus Epístolas escribió [a] Eustoquia, noble virgen romana, cosas de donaire y pasatiempo, para que de mejor gana las leyese y más a la memoria las encomendase. Y San Gregorio, también doctor sagrado, mezcló ejemplos y cuentos graciosos en los diálogos que escribió a su discípulo Pedro Diácono. E usaron también estas maneras de escribir Remigio y Abiano, y el Boccaccio, autores extraños de la nación española (f. 3).

94 Sin ir más lejos, la polémica naturaleza moral de las Novelas ejemplares subrayada por Cervantes en el prólogo: "Heles dado el nombre de Ejemplares, y si bien lo miras no hay ninguna de quien no se pueda sacar algún ejemplo provechoso; y si no fuera por no alargar este sujeto, quizá te mostrara el sabroso y honesto fruto que se podrá sacar, así de todas juntas como de cada una de por sí" (ed. cit., pp. 17-18). El estado de la cuestión sobre el tema se trata en pp. lxxxxix-xcv. Téngase en cuenta que en la Aprobación, Salas Barbadillo las califica como "Novelas ejemplares de honestísimo entretenimiento" (p. 8) y que el término aparece también en la traducción de Straparola, Honesto y agradable entretenimiento de damas y galanes (Bilbao, 1580), por ejemplo. 
En la nómina sólo Boccaccio resulta ser un lugar común como autoridad novelesca. Pero se muestra a las claras que después de la prohibición de su lectura en el Índice expurgatorio de 1559 había que hacer importantes reparos a la inmoralidad del Decamerón $n^{95}$ :

Aunque éste, en muchas cosas escedió los límites de la honestidad, los cuales con cuidado he yo procurado no traspasar, porque si las obras semejantes a esta mía, antiguamente, como he dicho, se llamaban consejas, por los buenos consejos y ejemplos que de ellas emanaban, no se podrían llamar tales las mías, si de ellas se pudiese tomar cosa contra honestidad y buen ejemplo (ff. 3-3v).

En el límite de la honestidad, pues, se circunscribe siempre la escritura de Salazar, tal como él mismo argumenta: “...procuré yo escribir por términos tan moderados y palabras tan medidas que espero en Nuestro Señor no se notará en ellas alguno de los dichos escesos" (f. 3v).

A este programa literario le corresponde una estructura didáctica que se va conformando, ya integrada en el plano de la ficción, a lo largo del marco narrativo. Al final del Fundamento, el arzobispo de Toledo es el encargado de establecer los parámetros estéticos que habrán de regir los cuentos que van a contársele al rey, en consonancia con las premisas autoriales ${ }^{96}$.

Pues ya vuestra alteza a preveído en esto lo que convenía y le habemos suplicado y parésceme salvo su mejor juicio y parecer, no tengan causa ni razón para se quejar de nosotros les avisemos y así les avisamos y advertimos que los cuentos que dijeren sean dignos de ser ante vuestra realeza relatados y traten de materias verisímiles y sean con buen estilo y gracia y palabras honestas explicados y que cualquier que contare y faltare en estas condiciones o en cualquier de ellas no pueda entrar sobre esto juicio, ni tenga derecho a los premios por vuestra alteza prometidos (ff. 6v-7).

95 Sobre la recepción de las novelas italianas en el contexto contrarreformista, véase CARMEN R. RABELL, Rewriting the italian novella in CounterReformation Spain, Tamesis, London, 2003.

${ }_{96}$ Estas prevenciones coinciden muy notablemente con los consejos de Lucas Gracián Dantisco, en el Galateo español, XVII sobre cómo han de ser los cuentos o novelas: “...que no tenga palabras deshonestas, ni suzias, ni tan puercas que puedan causar asco a quien le oye; pues se pueden dezir por rodeos y términos limpios y honestos... Y tales pueden ser las novelas o cuentos que, allende del entretenimiento y gusto, saquen dellas buenos ejemplos y moralidades" (ed. cit., p. 155). 
La estructura didáctica ulterior que enlaza con estas palabras del Fundamento se plasma en las consecuencias que extrae el rey del cuento inmediatamente después de haberlo oído y en los comentarios posteriores del juez encargado de valorarlo. No todas las aseveraciones conllevan el mismo grado de implicación moral y algunas de ellas simplemente se dedican a reflexionar sobre la bondad o maldad de los personajes en sus actuaciones, como ocurre en los cuentos 2, 3 o 4 . Como ya se ha comentado, las palabras regias sobre el ejercicio de la justicia en relación con el cuento 1 son esclarecedoras acerca de la opinión de Salazar al respecto. También sobre la justicia tratan las palabras del rey tras el cuento 10, que parecen extrapolarse hacia la práctica cotidiana: "No ternía yo por mala habilidad la que entre las tres ninfas discerniese cuál mejor mereció a Hipólito. Ellas se metieron en mucho trabajo y el juez a quien demandaron justicia la hace tan pocas veces que a ninguna de ellas aliviara la pena el ref[r]igerio de las sentencias les podría emanar" (f. 27lv). A lo que contesta el duque de Cantabria, que "Hipólito recibió mala obra en la dilación de la exención de las sentencias y si yo fuera tan venturoso que me viera en otra contienda semejante procurara convenirme con las partes de manera que no fuera menester ir a juicio ni esperar sentencia tan tardía" (f. 271v).

Ahora bien, especialmente interesantes son los comentarios relativos al amor y el matrimonio, eje temático, como sabemos, de gran parte de los cuentos. Como cabía esperar, los juicios sobre la cuestión amorosa afloran también en esas reflexiones. Fundamentalmente se hace hincapié en la necesidad de domeñar los impulsos sensuales hasta el momento del matrimonio. Así, el conde Eurico comenta con respecto al cuento 6, lo cual puede funcionar como guía de comportamiento para los jóvenes:

...la materia ha sido cual vuestra alteza dice y muy digna de ser encomendada a la memoria para que la gente que está en floreciente edad aprenda a resistir sus naturales inclinaciones y acidentales apetitos y deseos como Narses hizo que tiniendo en su poder a la hermosa Oridiana de quien tan enamorado se sintía no se quiso aprovechar de ella por no hacer cosa contra su voluntad y se hizo a sí mismo penosa fuerza por no lo hacer a la razón y a la que su corazón amaba (ff. 165-165v).

Por su parte, el rey subraya la actitud de la pareja protagonista del cuento 7, en su resolución firme para luchar por su amor: 
Cuando la ponzoñosa hierba del amor, dijo el rey, en el humano corazón de veras prende grande es el ánimo y aliento que pone al amante para emprender en cosas a sus fuerzas excesivas y sobre pujantes veis ahí a Otenrico que siendo de tan poca edad se atrevió a dejar los buenos tratamientos y regalos de su madre y a someterse a los peligros del espantable mar por ir a ver la que su corazón había herido. Y ella, después comenzada a tocar de la venenosa flecha, siendo también niña regalada, delicada y de su natural temerosa, pospuso todo el regalo y temor y cobró osadía para se disponer a los peligros que se dispuso por complacer a quien amaba (ff. 189-189v).

Y, a la zaga, el obispo Leandro confirma la fuerza del amor, pero sin dejar de recalcar que finalmente la buena consecución de los casos de amores se debe a la intervención de la Providencia:

Verdad es, serenísimo señor, dijo Leandro, arzobispo de Cartagena, que amor hace posibles cosas que parecen imposibles, empero si Dios con su divina clemencia no se apiadara de los dos amantes caído habían en manos de los verdugos ejecutores de la pena de su pecado y liviandad (f. 189v).

No obstante, el dictamen más importante de todos, que de nuevo refuerza la concepción de un amor matrimonial y sancionado por Dios, lo constituyen las últimas palabras que enuncia el rey a partir del cuento 10 y que habrán de suponer la conclusión ejemplar que resuena en las mentes de los lectores al acabar la obra. El amor se presenta como una lucha constante que lleva a los hombres a perder sus bienes terrenales y espirituales:

Vos, duque, dijo el rey, sois amigo de brevedad y las cosas del amor requieren mucha fe ma[s] porque su[e]len ser largas sus esperanzas y no poco penosas, por lo cual tengo yo por avisado a los que huyen de sus lazos y procuran escusarse de semejantes pleitos y contiendas que acarrean perdición para las haciendas, detrimentos para las vidas y, lo que peor es, desasosiego para los espíritus y peligros para las ánimas (f. 271v).

\section{Y CUATRO NOVELAS MÁS}

En 1992, en el número 55 de la revista Criticón, apareció un artículo de Gema Vallín y Gemma Avenoza ${ }^{97}$ donde presenta-

97 "Los primeros pasos de la novella en España: Cuatro quentos de ejemplos", Criticón, 55 (1992), 31-40. 
ban Cuatro cuentos de exemplos copiados en el ms. BNM 22026 (ff. 1-58v) ${ }^{98}$ y procedentes también (iqué casualidad!) de la colección de Phillips (ms. 6660). Con ello pretendían dilucidar los primeros pasos de la novella en España. Su trabajo es eminentemente codicológico ${ }^{99}$ y el primer hecho curioso que se deduce del estudio del manuscrito es que, mediante el análisis material, la fecha que las autoras asignan a los apólogos se sitúa en el margen de 1570-1576 $6^{100}$, coincidentes en gran medida con las barajadas anteriormente. En cuanto a la naturaleza de los cuentos, se limitan a ofrecer un resumen de las cuatro piezas ${ }^{101}$, pero de modo aislado, sin reparar, o sin explicitarlo al menos, en que existen restos de un marco narrativo en tres de las novelas $(1,2$, 4). Yendo yo mismo al manuscrito, y siguiendo el llamado de una intuición que se confirmó a la postre, me percaté de que en los fragmentos de ese marco narrativo se reflejan los mismos procedimientos que en la colección de Salazar, de lo cual he llegado a deducir que se trata de un resto desgajado de la segunda o tercera partes de las novelas hoy perdidas.

Reparemos ahora en esos indicios. En el cuento 1 (Cuento del castigo que envió Dios a un rey por sus pecados y soberbia y cómo se arrepintió y salió dellos) el narrador dice al principio: "Ácuérdome, muy alto príncipe y señor, haber leído en cierto autor latino..." (f. 1) ${ }^{102}$.Y, tras el cuento, habla un rey, que extrae consecuencias morales del mismo ${ }^{103}$, y luego interviene el arzobispo de Sevilla, en calidad de juez ${ }^{104}$. La novela 2 (Cuento de cómo

98 La sección se denomina Varios apólogos.

${ }^{99}$ Ello me exime de prestar atención aquí a la Descripción del manuscrito (art. cit., pp. 32-37).

100 Incluso en un momento dado afirman que "las fechas que se barajan rondan al año en que fue publicado El Patrañuelo, esto es 1567” (p. 32).

101 Aunque sobre el cuento primero se extienden un poco más, puesto que señalan su fuente concreta (pp. 37-40).

${ }_{102}$ Cito directamente del manuscrito, modernizando la grafía.

103 "El ingrato desconocido, dijo el rey acabado el cuento, que no conoce las mercedes que Dios le ha hecho ni le da gracias por ellas justísimamente merece parecer las adversidades y miserias que el Belerio padeció y mayormente aquellos que han venido a subir a estados reales y altivos en señoríos y otras cosas porque en cuanto el hombre se vea en más alta cumbre tanto más está obligado a humillarse y ser grato a quien le ensalzó y encumbró que es Dios que le pudiera hacer el hombre más pobre y abatido que hubiera en los nacidos" (f. 11v).

104 "Crea vuestra alteza, dijo el arzobispo de Sevilla, que son muchas veces los infortunios de los cuerpos y temporalidades muy prósperas fortunas para las almas y bien claro se mostró en este rey de quien se ha tratado 
una gentil matrona romana, siendo muy persiguida de un fraile le pagó como merecía) se dirige también a "Vuestra Alteza"105 y el narrador del marco remata diciendo, igual que en las Diez novelas de Salazar, que "Grandemente gustó el rey de la virtuosa cautela de Antonina para con fray Lupercio" (f. 24). Y luego sigue un breve parlamento entre el rey y el Condestable de Castilla sobre la actuación de los personajes ${ }^{106}$. Por desgracia, en el cuento 3 (Cuento de cómo por culpa de su madre una doncella perdió la honra y padeció mucho trabajo) se han perdido los vestigios del marco. Pero en el 4 (Cuento de cómo un conde de Rensburg procuró mucho la muerte de un hijo de un caballero alemán y cómo no quiso Dios que hubiese efeto en su mal deseo), además de las intervenciones consabidas del rey ${ }^{107}$ y del juez de turno ${ }^{108}$-de nuevo el Condestable-, el narrador establece una marca espacio-temporal, paralela a las de las Diez novelas: "Y diciendo el Condestable estas palabras, llegaron a vista de muchos donde el rey reposó aquella noche y tomando el día siguiente su camino" (f. 58v). Lo cual indicaría que podría tratarse de la novela décima de la parte correspondiente. Sólo se ha perdido, en definitiva, la intervención de cada narrador tras las del rey y el juez, donde expresa sus repa-

porque si Dios no le trajera a la miseria a que le trujo jamás viniera en conocimiento de su error y pecado y mediante las adversidades y calamidades que le vinieron parece fue Dios servido darle gran poder para ayudarse a levantar de su profunda culpa" (f. 11v).

105 "Sabrá Vuestra Alteza que en Begonia (Bolonia), nobilísima ciudad de Lombardía, la cual es llena de parcialidades y bandos, fue morador en la calle Barboci un gentilhombre llamado Curcio..." (f. 13).

106 "...y el Conde estable de Castilla, que no menos gusto había recibido, le dijo: “-¿Qué le parece a vuestra alteza [que no menos gusto] cuán buena romana fue Antonina? -Paréceme, dijo el rey, que con justo título le debiera ser concedido triunfo, pues consiguió tan victoriosa victoria en engañar y escarmentar un fraile. -Señor, dijo el conde estable, mediante las armas con que ella peleaba esas y otras más dudosas victorias se alcanzan. -Es verdad, respondió el rey, porque era amor de Dios y de su marido, celo de su honra y honestidad que son armas, contra cuyo poder no hay lanza honesta" (ff. 24-24v).

107 "Dañosas son muchas veces las letras, dijo el rey, a los que se aprovechan mal de ellas y así fueron a ese desventurado de Doronspel, pues por saber lo que sabía le tomó ganas de saber lo que no debiera. Ese deseo le trujo por sus pasos contados a dar en la celada de su siniestro hado" (f. 58v).

108 "Ciertamente, Serenísimo señor, dijo el Condestable, saber lo futuro y por venir a sólo Dios es dado y esta es una de las cosas especialmente reservadas a su omnipotencia y divina sabiduría, por lo cual será bien que los hombres se desviasen de querer considerar las figuras y movimientos celestes para tener noticias de cosas que no han sido ni son, pues es suyo entender lo pasado y presente y de sólo Dios saber lo futuro y venidero" (id.). 
ros para la narración del cuento previsto, pero hay que tener en cuenta que las novelas en este manuscrito están desgajadas del todo y no muestran una continuidad.

Creo que no cabe duda posible al respecto. Estos cuatro cuentos son también de Salazar y forman parte de su proyecto completo, auque no podamos asegurar que su disposición inicial fuera contigua, tal como se presentan ahora en el manuscrito. Pero las concomitancias salen una y otra vez al paso, si reparamos en otros aspectos, como los paralelismos estilísticos y léxicos o la afinidad en los argumentos y varios extremos más. Hay, por ejemplo, dos coincidencias externas que convergen en el mismo sentido. En primer lugar, la igualdad en los epígrafes, planteados en su mayor parte mediante la expresión Cuento de cómo, etc. Y en segundo término, los restos que se observan en los cuatro cuentos de ese procedimiento de dividir la narración en secuencias más cortas, tal como hace Salazar en las Diez novelas. El recuento de esas partes nos lleva a identificar ahora una extensión paralela. Se observa una progresión ascendente, de tal modo que el primer cuento es el más corto, con siete unidades, pasando por las nueve y diez, del 2 y 3 , hasta las trece del 4 .

Basarse en recurrencias léxicas o estilísticas puede resultar un medio discutible para la identificación de la autoría compartida, pero, sin duda, las expresiones comunes son tantas que no pueden ser un hecho casual. Con todo, sólo señalaré dos elementos de los muchos concomitantes. Por un lado, uno gramatical e inconsciente. Los cuatro cuentos hacen uso sistemático del laísmo, al igual que las diez novelas, rasgo típicamente madrileño, como se declara Salazar en sus escritos. Pero sobre todo, uno segundo, ornamental e intencionado. En ambas series de relatos se emplea un tipo de comparaciones muy peculiar, que no pueden haber salido de la pluma de un autor diferente. Las actuaciones de los humanos se parangonan a menudo con reacciones animales o minerales y a veces con otros congéneres. En los Cuentos se dice, por ejemplo: “...sin le aprovechar hacer fuerza de obras ni palabras le sacaron de la cámara a la sala donde, como toro en el coso que está cercado de los toreadores y uno le tira la garlocha y otro la capa y otro la piedra y otro le da el palo y otro le sirba y grita, así el rey fue cercado de los pajes" (f. 6v); "... el rey, que de su pecado estaba muy descuidado, como aquel a quien se le quita la niebla cerrada de delante y que lo tiene ocupado lo largo de la vista” (f. 9v); o “...así se azoró como el alano, cuando muerto de hambre, arremete al señuelo cuando 
le llaman" (f. 17). Y en las Diez novelas, entre otros varios símiles aparecen los siguientes: "y yendo contino con la gran fuerza del amor que llevaba, derritiéndose como la fría nieve de los calidísimos rayos del sol combatida" (ff. 60v-61); "por sus pecados tantas a su voluntad, que, como abeja en la florida primavera anda picando en una flor y en otra, de la misma manera Astrofen gozaba de esta y aquella y la otra” (f. 106); “...que con título de amor limpio le había dado, como el platero que, antes que comience a labrar el fino diamante, lo unta primero con sangre de cabrón para enternecer su rudeza...” (f. 110); “...lo cual oyendo Clitemnestra, como el jabalí que arremete con gran furia hacia donde oyó sonar el golpe o chasquido de la ballesta con que le tiraron el crudo pasador, comenzó a correr contra el palacio..." (f. 228); "con el ansia que llevaba, hendiendo por entre todos, como hiende el caudaloso río las saladas aguas cuando en el mar entra, llegó hasta el palacio..." (f. 228); o "y el cuerpo pesaba tan bien que, como el asno muy flaco que con la pesada carga, atollado en el lodazar, menea la cabeza y se rebulle por levantarse y el peso de la carga no le deja, antes le tiene siempre debajo, ansí el pobre hombre, aunque más procuraba volverse y revolverse..." (f. 250). Me parece que el grado de convergencia habla por sí solo y no hay más que decir al respecto.

Desde el punto de vista literario, también se observan coincidencias argumentales entre las novelas. El primer cuento trata sobre la soberbia de los poderosos y tiene una fuente bien conocida. De hecho, es la única vez que el autor declara basarse en un texto previo ${ }^{109}$. Probablemente se refiera a la Gesta romanorum, número 59, que conoce luego extensiones romances en Juan Manuel, 51, o Sercambi, De superbia contra rem sacratam ${ }^{110}$. El rey de Macedonia, llamado Belerio, está presente con su esposa en las vísperas del Corpus, pero durante el Magníficat ${ }^{111}$ se va de la Iglesia indignado, creyendo que no se puede estar más alto en la rueda de Fortuna. Su soberbia recibirá entonces el merecido castigo divino: durante una cacería, el rey se pierde en el bosque, que está envuelto en llamas, y se dirige hacia una fuente para refrescarse de las quemaduras. Un ángel, que está allí,

\footnotetext{
109 "Acuérdome, muy alto príncipe y señor, haber leído en cierto autor latino..." (f. 1).

110 Thompson (Rey orgulloso desplazado por un ángel), L411.

111 Compárese con Amton Francesco Doni, Lettere, XII: Racconto la novella del vecchio, che cantava il "Magnificat" (Le novelle, Salerno, Roma, 20022003, p. 424).
} 
se lleva sus vestidos y suplanta su persona -incluso acompaña a palacio a los compañeros de montería. Belerio tiene que volver a pie; en su casa nadie lo reconoce -tan deformado está su semblante-, por lo que lo echan a la calle y se ve obligado a vagar de un sitio a otro pidiendo limosna. Recurre entonces a la ayuda de un monje, su antiguo padre espiritual, quien lo acoge -todavía tardará unos días en confesar su culpa. Una vez reconocido su pecado, recupera su dignidad y todos lo reconocen. Esta caída a causa de una culpa y su recuperación posterior por la confesión de la falta guarda ciertas concomitancias con los hechos del cuento segundo, donde el pecado que se castiga es la deslealtad por avaricia, y, en cierta medida, también con el octavo, en que el rey también se hace mendicante hasta su restitución final.

Muy diferente a este primero, el cuento segundo plantea un argumento típicamente boccacciano, a partir de un intento de seducción fallido, y resulta bastante paralelo en su comicidad al cuento cuarto de la primera década. El joven Lupercio, después de haber seducido a todas las mujeres hermosas de Bolonia, no tiene más remedio que cumplir el mandato de su padre con objeto de escapar de los maridos despechados. Para ello ingresa en un convento de Roma, pero con la excusa de pedir limosna sale para volver a sus consabidos escarceos. En una de las casas conoce a Antonina, esposa de un patricio romano, y usa todas las tretas posibles, si bien no con mucho éxito, para enamorar a la dama -incluido el acercamiento galante a su criada. De tanto insistir, la dama, aprovechando una ausencia del marido, lo recibe en su aposento, aunque en realidad lo que le prepara es un castigo por su osadía, haciendo que caiga en un aljibe ${ }^{112}$ donde creerá morir.

El tercer cuento pertenece a la categoría de amores, aunque con la variante, desconocida hasta el momento en Salazar, de entrañar relaciones fuera del matrimonio. La viuda del duque de Lorena acude a la corte de su hermano, el rey de Francia, Luis I, con la idea de encontrar un buen partido para su hija Margarita. A ésta comienza a cortejarla Ludovico, el heredero del señor de Gascuña. La madre le aconseja que sea complaciente con él y Margarita consiente en dejarse seducir, pero el príncipe intuye que su padre no verá con buenos ojos el matrimonio. En efecto, cuando éste sabe de los amores de su hijo lo requiere a su lado. Entre tanto, Margarita, que ha quedado embarazada,

112 Muy similar es lo que ocurre en Decamerón, VIII, 9. 
huye de la corte acompañada de su doncella Leonora. Vestidas de romeras, llegan a Bayona, donde conocen la noticia de que Ludovico se ha casado con la hija del rey de Navarra ${ }^{113}$; Margarita decide entonces recluirse y hacerse ermitaña para pagar su culpa. Han pasado cinco años, Ludovico - quien ha enviudado y perdido a su padre- acude a una cacería durante la cual se encuentra casualmente con Margarita. Ludovico se arrepiente de sus actos y la desposa; además, reconoce a su hijo como heredero. Margarita, sin embargo, muere, y Ludovico, para que quede memoria de la virtud de su esposa, levanta un monasterio en la antigua ermita.

En efecto, estos dos cuentos proponen dos situaciones amorosas fuera del matrimonio, la primera de claro signo adulterino y la segunda de seducción y posterior embarazo. Pero hay que tener en cuenta que esta situación inicial queda en ambos finalmente reparada. En el segundo, mediante el engaño de la dama, que aunque da esperanzas iniciales al amador, pretende realmente su ultraje. En el tercero -donde, en definitiva, la última culpable es la madre alcahueta ${ }^{114}$, , las marcas de reprehensión son mayores. La amada se recluye en la soledad eremítica con una finalidad penitencial y el seductor se arrepiente, casándose finalmente con la dama deshonrada y reconociendo a su hijo. Por tanto, también se les puede inscribir sin dificultad en el ámbito moral.

Por último, en el cuarto cuento, Salazar integra diversos motivos de claras resonancias tradicionales, tales como la profecía - un niño que ha de nacer excelente-, la adopción de una criatura y la suplantación de la personalidad, así como la posterior liberación de la princesa y la consecución del trono. En concreto, un sabio conde, experto en las artes astrológicas, al consultar el zodiaco llega a saber que un recién nacido, Federico, lo superará en sabiduría y estado ${ }^{115}$. Temiendo por su fortuna, echa mano de todos los medios a su alcance para buscar su muerte: convence al rey, pariente de los flamantes padres, de que en realidad el niño irá contra sus intereses. Sin embargo, la criatura se salva -porque el encargado de ejecutar la muerte

113 Para el motivo de La novia abandonada, A. AArne y S. Thompson, Los tipos..., 884 (T102).

114 Es el argumento de los Siete sabios, XII.

115 Los motivos tradicionales relativos a la profecía y el destino son muy profusos. Por ejemplo, A. Aarne y S. Thompson, Los tipos..., 930-949, motivo M312, S143. 
le perdona la vida-, y un matrimonio de Gante lo educa como hijo ${ }^{116}$-convenciendo, para ello, a la pareja de pastores que lo recibieron inicialmente. Cuando el joven cumple 20 años va en busca de sus verdaderos padres, pues se ha enterado de que en su momento fue adoptado. En su camino, se encuentra con la hija del rey que ha sido atacada por un oso y la libera de sus garras, momento a partir del cual se produce el enamoramiento mutuo. Pero los adelantos de Charles -nombre con el que se le conoce en la corte-, llegan a oídos del conde, que lo identifica con el niño que quería matar. Aunque vuelve a intentarlo, engañando otra vez al rey, fracasa de nuevo en su propósito de acabar con la vida del muchacho. Incluso lo pretende una tercera vez, implicando a sus propios sobrinos en su propósito. No le servirá de nada, porque la princesa, tras la muerte de su padre, heredará pronto el trono, y se casará con Charles, quien de ese modo se convierte en rey, cumpliendo finalmente el vaticinio.

A tenor de lo visto, en definitiva, se puede concluir que las desde ahora catorce novelitas de Pedro de Salazar constituyen el primer ejemplo en España -y no entonces las Patrañas de Timoneda, como se ha venido manteniendo hasta ahora-, de las colecciones de novelas cortas a la italiana, en este caso, con marco narrativo. Una obra de este tipo tenía como fin último, seguramente, su difusión impresa, quizá en volúmenes sucesivos con sus diferentes partes. Lo cierto es que, debido a no sabemos qué motivos o circunstancias, las novelas quedaron relegadas a su sola existencia en dos manuscritos que, dada la importancia de los textos que copian, merecen ser de nuevo recuperadas ${ }^{117}$.

VALENTín NúÑez Rivera Universidad de Huelva

116 La adopción aparece, por ejemplo, en el cuento 21 del Príncipe Erasto.

117 Este trabajo supone, en definitiva, un adelanto de la edición de las novelas de Salazar, que estoy ultimando. 
